\title{
Genetic Variability and Association of Yield Attributing Traits of Rice Collections of Assam and Arunachal Pradesh
}

\author{
Sujata Das ${ }^{1}$, Lotan Kumar Bose ${ }^{2}$, Bhaskar Chandra Patra ${ }^{2}$, Nitiprasad Namdeorao \\ Jambhulkar $^{2}$, Sudipti Mohapatra ${ }^{2}$ and Priyadarsini Sanghamitra ${ }^{2}$ \\ ${ }^{1}$ Regional Research and Technology Transfer Station (OUAT), Keonjhar, \\ Dhenkanal, Odisha, India \\ ${ }^{2}$ Crop Improvement Division, ICAR-National Rice Research Institute, Cuttack - 753006, India \\ *Corresponding author
}

\section{A B S T R A C T}

\section{Keywords}

Rice, Correlation, Direct effect, Genetic advance, Heritability, Path analysis

Article Info

Accepted:

20 March 2019

Available Online:

10 April 2019
A study was undertaken to find out the genetic variability and correlation between yield and other yield attributing characters of rice genotypes of Assam and Arunachal Pradesh. The experiment was conducted with fifty four genotypes grown during Wet season under transplanted condition in a randomized complete block design. Analysis of variance shows significance in all the traits indicating the presence of considerable amount of genetic variation among the genotypes. The traits like grain yield/plant and tillers/plant has high genotypic coefficient of variation and phenotypic coefficient of variation; while plant height and days to $50 \%$ flowering has high genetic advance. Plant height, leaf width and panicle length were positively and significantly correlated with yield. Tillers/plant and plant height has high direct effect on yield. Therefore, selection based on plant height and tillers/plant could be more effective in rice yield production of Assam and Arunachal Pradesh.

\section{Introduction}

Rice (Oryza sativa L.) is the staple food for a large proportion of the world's population (Zhang, 2007). The world population is expected to reach 8 billion by 2030 and rice production must be increased by $50 \%$ in order to meet the growing demand (Khush and Brar, 2002). Hence breeders should target at developing cultivars with improved yield and other desirable agronomic characters. The presence and magnitude of genetic variability in a gene pool is the prerequisite of breeding programme. Heritability estimates provides the information on the proportion of variation that is transmissible to the progenies in subsequent generation. Genetic advance provides information on expected genetic gain resulting from selection of superior individuals. Grain yield is a complex quantitative governed character and an integrated function of a number of component characters. Therefore, selection for yield per se may yield satisfactory result. Yield 
contributing traits are interrelated and highly influenced by the environments (Chandra et al, 2007; Nayak et al., 2008; Prasad et al., 2001; Eswara Reddy et al., 2013) and partitioned into direct and indirect effect for yield (Mohsin et al., 2009). Efficiency of indirect selection depends on the magnitude of correlations between yield and target yield components (Toker and Cagirgan, 2004; Bose et al., 2007; Idris et al., 2012; Dhanwani et al., 2013; Pratap et al., 2014). Instead of direct selection for yield per se which is not of much use, selection through other yield attributing characters may yield better results. Correlation study provides a measure of association between characters and helps to identify the important yield attributing characters. The path analysis has been used by plant breeders to support in identifying traits that are promising as selection criteria to improve crop yield and to detect the amount of direct and indirect effect of the causal components on the effect component (Bose et al., 2005; Indu Rani et al., 2008; Togay et al., 2008; Ali et al., 2009; Chandra et al., 2009; Akhatar et al., 2011; Cyprian and Kumar, 2011; Jambhulkar and Bose, 2014).Selection on the basis of yield components to increase grain yield components would be most effective, if the components involved are highly heritable and genetically independent or positively correlated with grain yield. Keeping in view this urgent need, this investigation was undertaken to understand the genetic variability and correlation between yield and other yield attributing characters under selected ecology.

\section{Materials and Methods}

The materials for the present investigation consisted of 54 land races collected in 2010 from different parts of Arunachal Pradesh and parts of upper Assam which is the eastern stretch of the Himalayas (Table 1). The collected samples along with four popular checks were grown in randomized complete block design with three replications during wet season 2011 in irrigated land at experimental plot of NRRI, Cuttack. Thirtyday-old seedlings were transplanted in six rows/entry, each row having 30 hills with single seedling/hill and $20 \times 15 \mathrm{~cm}$ spacing. Nine quantitative traits viz. plant height, leaf length \& width, panicle length, ear bearing tiller/ plant, seed test weight (100), single plant yield and grain length/breadth ratio were recorded on five randomly selected plants excluding the border rows from each entry. Days to $50 \%$ flowering was recorded on plot basis. Analysis of variance (ANOVA) was carried out on the data to assess the genotypic effects. Estimates of variance components were generated. Broad-sense heritability $\left(h^{2}\right)$ was calculated as the ratio of the genotypic variance to the phenotypic variance using the formula (Allard, 1960). Genetic advance was calculated at $20 \%$ selection intensity. Phenotypic coefficient of correlations was also computed. The statistical analysis was done using SAS 9.2 software.

\section{Results and Discussion}

The analysis of variance exhibited highly significant differences among various genotypes for the nine characters under study. This indicated that the genotypes were having inherent genetic variances among themselves with respect to the character studied. The analysis of variance for nine characters of 54 rice genotypes revealed high estimate of genotypic and phenotypic coefficient of variation for grain yield per plant (35.74 and 36.09 respectively), Number of productive tillers/plant (24.95 and 25.45 respectively), leaf width (18.77 and 18.86 respectively), grain length/breadth ratio (18.12 and 18.35 respectively). A moderate value of $\mathrm{PCV}$ and GCV for leaf length, panicle length, 100 grain weight, plant height, days to $50 \%$ flowering were recorded which may be due to the 
presence of both positive and negative alleles in the population. Narrow difference between PCV and GCV for characters like Days to $50 \%$ flowering, plant height, leaf length, leaf width, panicle length, 100 grain weight suggested a limited role of environmental variation in the expression of these characters, suggested that selection based on phenotypic performance of the characters would be effective to bring about considerable improvement in these characters. The estimates of heritability were observed to be high in magnitude for all characters ranging from 96.1 to 99.8 . High heritability coupled with high to moderate genetic advances were found in plant height $\left(\mathrm{H}^{2}=99.8, \mathrm{GA}=45.78\right)$,
Days to flowering $\left(\mathrm{H}^{2}=99.7, \mathrm{GA}=25.3\right)$, leaf length $\left(\mathrm{H}^{2}=98.9, \mathrm{GA}=14.3\right)$, Panicle length $\left(\mathrm{H}^{2}=98.1, \mathrm{GA}=5.82\right)$, Number of productive tillers/plant $\quad\left(\mathrm{H}^{2}=96.1, \quad \mathrm{GA}=3.03\right), \quad$ Grain length/breadth $(\mathrm{H} 2=97.5, \quad \mathrm{GA}=1.1)$, grain yield $\left(\mathrm{H}^{2}=98.1, \mathrm{GA}=8.48\right)$ suggested that these traits are primarily under genetic control and selection for them can be achieved by their phenotypic performance. High heritability with low genetic advance was observed for leaf width $\left(\mathrm{H}^{2}=99, \mathrm{GA}=0.41\right), 100$ grain weight $\left(\mathrm{H}^{2}=99.3, \mathrm{GA}=0.79\right)$, indicated non additive type of gene action and presence of significant role of genotype $\mathrm{x}$ environment interaction in expression of them (Table 2-4).

Table.1 Analysis of variance for nine characters of 58 rice genotypes

\begin{tabular}{|l|c|c|c|}
\hline \multirow{2}{*}{ Characters } & \multicolumn{3}{|c|}{ Sources of variation } \\
\cline { 2 - 4 } & Replication(2) & Genotypes(57) & Error (114) \\
\hline Days to 50\% flowering & 0.121 & $452.542 * *$ & 0.483263 \\
\hline Plant height & 0.077 & $1484.659^{* *}$ & 0.801974 \\
\hline Leaf length & 0.732 & $146.248^{* *}$ & 0.554118 \\
\hline Leaf width & 0.004 & $0.123^{* *}$ & 0.000432 \\
\hline Panicle length & 0.211 & $24.545^{* *}$ & 0.161031 \\
\hline Tillers/plant & 0.019 & $6.831^{* *}$ & 0.092064 \\
\hline 100 grain weight & 0.005 & $0.446^{* *}$ & 0.001107 \\
\hline Grain length/breadth & 0.008 & $0.881 * *$ & 0.007402 \\
\hline Grain yield/plant & 9.688 & $52.104 * *$ & 0.337952 \\
\hline
\end{tabular}

** significant at $1 \%$ probability level

Table.2 Estimates of mean, range, CV, GCV, PCV, heritability and genetic advance of nine Characters

\begin{tabular}{|l|l|l|l|l|l|l|l|r|}
\hline Characters & Mean & Range & CV\% & GCV\% & PCV\% & H $^{\mathbf{2}}$ & GA\% & Env Var \\
\hline $\begin{array}{l}\text { Days to 50\% } \\
\text { flowering }\end{array}$ & 121.41 & $91.33-138.00$ & 57.26 & 10.11 & 10.13 & 99.7 & 25.247 & 0.02 \\
\hline Plant height & 129.95 & $77.83-183.25$ & 68.91 & 17.11 & 17.13 & 99.8 & 45.78 & 0.02 \\
\hline Leaf length & 45.20 & $30.47-62.24$ & 164.65 & 15.42 & 15.50 & 98.9 & 14.28 & 0.08 \\
\hline Leaf width & 1.08 & $0.68-1.66$ & 192.99 & 18.77 & 18.86 & 99.0 & 0.41 & 0.09 \\
\hline Panicle length & 25.41 & $17.29-31.75$ & 157.88 & 11.22 & 11.33 & 98.1 & 5.82 & 0.11 \\
\hline Tillers/plant & 6.00 & $3.25-9.73$ & 505.02 & 24.95 & 25.45 & 96.1 & 3.03 & 0.5 \\
\hline 100 grain weight & 2.28 & $0.94-2.85$ & 145.89 & 16.89 & 16.95 & 99.3 & 0.79 & 0.06 \\
\hline $\begin{array}{l}\text { Grain } \\
\text { length/breadth }\end{array}$ & 2.98 & $1.88-4.45$ & 288.93 & 18.12 & 18.35 & 97.5 & 1.10 & 0.23 \\
\hline Grain yield/plant & 11.62 & $5.69-22.11$ & 500.14 & 35.74 & 36.09 & 98.1 & 8.48 & 0.35 \\
\hline
\end{tabular}


Table.3 Phenotypic correlation coefficients among nine traits in rice

\begin{tabular}{|c|c|c|c|c|c|c|c|c|c|}
\hline Characters & $\begin{array}{l}\text { Days to } \\
50 \% \\
\text { flowering }\end{array}$ & $\begin{array}{l}\text { Plant } \\
\text { height }\end{array}$ & $\begin{array}{l}\text { Leaf } \\
\text { length }\end{array}$ & $\begin{array}{l}\text { Leaf } \\
\text { width }\end{array}$ & $\begin{array}{l}\text { Panicle } \\
\text { length }\end{array}$ & $\begin{array}{l}\text { Tillers/ } \\
\text { plant }\end{array}$ & $\begin{array}{l}\text { Grain } \\
\text { length/ } \\
\text { breadth }\end{array}$ & $\begin{array}{l}100 \\
\text { grain } \\
\text { weight }\end{array}$ & $\begin{array}{l}\text { Grain } \\
\text { yield/ } \\
\text { plant }\end{array}$ \\
\hline $\begin{array}{l}\text { Days to } 50 \% \\
\text { flowering }\end{array}$ & 1.000 & $0.5230 * * *$ & $0.5047 * * *$ & -0.0468 & $0.2707 * * *$ & $-0.1997 * *$ & $-0.1575^{*}$ & 0.1019 & 0.1191 \\
\hline Plant height & & 1.000 & $0.6773 * * *$ & $0.2479 * * *$ & $0.5956^{* * *}$ & 0.0508 & -0.0304 & 0.0738 & 0.4462 \\
\hline Leaf length & & & 1.000 & $0.3093 * * *$ & $0.4511 * * *$ & 0.0487 & -0.0971 & $0.186^{*}$ & 0.4497 \\
\hline Leaf width & & & & 1.000 & 0.0360 & -0.0721 & 0.0659 & $\begin{array}{l}0.3214 * * \\
*\end{array}$ & 0.2841 \\
\hline Panicle length & & & & & 1.000 & $0.1743 *$ & 0.1236 & 0.0043 & 0.2255 \\
\hline Tillers/plant & & & & & & 1.000 & $-0.2181 * *$ & -0.1788 & 0.4205 \\
\hline $\begin{array}{l}\text { Grain } \\
\text { length/breadth }\end{array}$ & & & & & & & 1.000 & $-0.1561^{*}$ & -0.1660 \\
\hline $\begin{array}{l}100 \text { grain } \\
\text { weight }\end{array}$ & & & & & & & & 1.000 & 0.1188 \\
\hline $\begin{array}{l}\text { Grain } \\
\text { yield/plant }\end{array}$ & & & & & & & & & 1.000 \\
\hline
\end{tabular}

Table.4 Direct and indirect effect of eight different characters on yield

\begin{tabular}{|c|c|c|c|c|c|c|c|c|c|}
\hline Characters & $\begin{array}{l}\text { Days to } \\
50 \% \\
\text { flowering }\end{array}$ & $\begin{array}{l}\text { Plant } \\
\text { height }\end{array}$ & $\begin{array}{l}\text { Leaf } \\
\text { length }\end{array}$ & $\begin{array}{l}\text { Leaf } \\
\text { width }\end{array}$ & $\begin{array}{l}\text { Panicle } \\
\text { length }\end{array}$ & $\begin{array}{l}\text { Tillers/ } \\
\text { plant }\end{array}$ & $\begin{array}{l}\text { Grain } \\
\text { length/ } \\
\text { bread }\end{array}$ & \begin{tabular}{|l|}
100 \\
grain \\
weight \\
\end{tabular} & $\begin{array}{l}\text { Phenotypic } \\
\text { correlation } \\
\text { with Yield }\end{array}$ \\
\hline Days to $50 \%$ flowering & -0.0617 & -0.0323 & -0.0312 & 0.0029 & -0.0167 & 0.0123 & 0.0097 & -0.0063 & 0.1191 \\
\hline Plant height & 0.1808 & 0.3457 & 0.2341 & 0.0857 & 0.2059 & 0.0176 & -0.0105 & 0.0255 & 0.4462 \\
\hline Leaf length & 0.1164 & 0.1562 & 0.2306 & 0.0713 & 0.104 & 0.0112 & -0.0224 & 0.0429 & 0.4497 \\
\hline Leaf width & -0.0063 & 0.0333 & 0.0415 & 0.1343 & 0.0048 & -0.0097 & 0.0089 & 0.0432 & 0.2841 \\
\hline Panicle length & -0.0388 & -0.0853 & -0.0646 & -0.0052 & -0.1432 & -0.025 & -0.0177 & -0.0006 & 0.2255 \\
\hline Tillers/plant & -0.0845 & 0.0215 & 0.0206 & -0.0305 & 0.0737 & 0.4231 & -0.0923 & -0.0757 & 0.4205 \\
\hline Grain length/breadth & 0.0045 & 0.0009 & 0.0028 & -0.0019 & -0.0035 & 0.0062 & -0.0283 & 0.0044 & -0.166 \\
\hline 100 grain weight & 0.0087 & 0.0063 & 0.0159 & 0.0274 & 0.0004 & -0.0153 & -0.0133 & 0.0854 & 0.1188 \\
\hline Residual effect & & & & & & & & 0.7492 & \\
\hline
\end{tabular}

All the characters showed positive correlation except grain L/B which showed negative correlation with grain yield/plant. Characters showing high positive correlation with grain yield /plant are leaf length (0.4497), plant height (0.4462), No. of tillers /plant (0.4205) while characters like 100 grain weight, days to $50 \%$ flowering etc. showed low positive correlation with grain yield/plant. The phenotypic correlation coefficients are positive, high among plant height with leaf length (0.6773) and panicle length (0.5956) days to flowering (0.523), leaf length with days to flowering (0.5047) and panicle length (0.4511). This shows that these characters are interdependent. Selection of observable traits among these will ultimately enhance the mean performance of all the concerned interdependent characters.

The result revealed high estimates of GCV \& PCV (24.95) high heritability (96.1) for number of productive tillers and plant height which also have high significant correlation 
with grain yield/plant. Hence the selection based on these characters could be more effective in rice.

Genotypic path analysis studies revealed that all the characters showed positive direct effect except for grain length/breadth. The maximum positive direct effect were observed for tillers/plant (0.4231), plant height (0.3457), leaf length (0.234). Positive direct effect as well as correlation coefficient indicates that selection may be exercised for these traits for yield improvement.

The degree of correlation between the characters is an important factor especially in economic and complex characters like yield. The correlations are the measure of intensity of association between the traits (Steel and Torrie, 1984).

The selection for one trait results in progress for all positively correlated characters while retrogressed for negatively correlated characters.

In conclusion, the study of coefficient of variation, heritability, genetic advance and correlation analysis of the study revealed that the plant height, number of productive tillers, leaf length, panicle length were the most important yield components. These characters also showed high heritability and genetic advance in percentage of mean. Therefore, it was concluded that selection based on these traits would be most effective.

\section{References}

Akhtar, N., Nazir, M. F., Rabnawaz, A., Mahmood, T., Safdar, M. E., Asif, M. and Rehman, A. 2011. Estimation of heritability, correlation and path coefficient analysis in fine grain rice (Oryza sativa L.). The Journal of Animal \& Plant Sciences. 21(4): 660664.
Allard, R.W. 1960. Principle of Plant Breeding. John Wiley and Sons Inc.. New York, USA.

Ali, M. A., Nawad, N. N., Abbas, A., Zulkiffa, M. and Sajjad, M. 2009. Evaluation of selection criteria in Cicer arietinum L. using correlation coefficients and path analysis. Australian Journal of Crop Science. 3(2): 65-70.

Bose, L. K., Pradhan, S. K., Mohanty, A. and Nagaraju, M. 2005 Genetic variability and association of yield attributing characters with grain yield in deepwater rice. Korean Journal of Crop Science. 50(4): 262-264.

Bose, L. K., Das, S., Pradhan, S. K., Subudhi, H. N., Singh, S. and Singh, O. N. 2007. Genetic variability of quality characters and grain yield in lowland rice genotypes of Eastern India. Korean Journal of Breeding Science. 39(1): 1-6. Chandra, R., Pradhan, S. K., Singh, S., Bose, L. K. and Singh, O. N. 2007. Multivariate analysis in upland genotypes. World Journal of Agricultural Sciences. 3(3): 295-300.

Chandra, B. S., Reddy, T. D., Ansari, N. A. and Kumar, S. S. 2009. Correlation and path analysis for yield and yield components in rice (Oryza sativa L.). Agricultural Science Digest. 29(1): 4547.

Cyprian, M., and Kumar, V. 2011. Correlation and path coefficient analysis of rice cultivars data. Journal of Reliability and Statistical Studies. 4(2): 119-131.

Dhanwani, R. K., Sarawgi, A. K., Solanki, A. and Tiwari, J. K. 2013. Genetic variability analysis for various yield attributing and quality traits in rice $(O$. sativa L.). The Bioscan. 8(4): 14031407.

Eswara Reddy, G., Suresh, B. G., Sravan, T. and Ashok Reddy, P. 2013. 
Interrelationship and cause-effect analysis of rice genotypes in north east plain zone. The Bioscan. 8(4): 11411144.

Idris, A.E., Justin, F. J., Dagash, Y. M. I. and Abduli, A. I. 2012. Genetic variability and inter relationship between yield and yield components in some rice genotypes. American Journal of Experimental Agriculture. 2(2): 233239.

Indu Rani, C., Veeraragathantham, D., and Sanjutha, S. 2008. Studies on correlation and path coefficient analysis on yield attributes in Root Knot Nematode Resistant F1 hybrids of tomato. J Appl Sci Res. 4(3): 287-295.

Jambhulkar, N. N., and Bose, L. K. 2014. Genetic variability and association of yield attributing traits with grain yield in upland rice. Genetika. 46(3): 831838.

Khush, G. S., and Brar, D. S. 2002. Rice. Evolution and adaptation of crops (Chopra, V.L., S. Prakash Ed.). Vol. I, p. 1-41. New Delhi, Oxford and IBH Publ. Co.

Mohsin, T., Khan, N. and Naqvi, F. N. 2009. Heritability, phenotypic correlation and path coefficient studies for some agronomic characters in synthetic elite lines of wheat. Journal of Food Agriculture \& Environment. 7: 278-282.

Nayak, D., Bose, L. K., Singh, U. D., Singh, S. and Nayak, P. 2008. Measurement of genetic diversity of virulence in populations of Xanthomonas oryzae pv. oryzae in India. Communications in Biometry and Crop Science. 3(1): 1628.

Prasad, B., Patwary, A. K. and Biswas, P. S. 2001. Genetic variability and selection criteria in fine rice (Oryza sativa L.). Pakistan Journal of Biological Sciences. 4: $1188-1190$.

SAS Institute 2010. SAS/STAT Version 9.2. SAS Institute, Cary, North Carolina USA.

Pratap, N., Singh, P. K., Shekhar, R., Soni, S. K. and Mall, A. K. 2014. Genetic variability, character association and diversity analyses for economic traits in rice (Oryza sativa L.) SAARC Journal of Agriculture. 10(2): 83-94.

Steel, R. G. D., and Torrie, J. H. 1984. Principles and Procedures of Statistics: A Biometrical Approach. 2nd McGraw Hill Book Co., Singapore.

Togay, N., Togay, Y., Yildirin, B. and Dogan, Y. 2008. Relationships between yield and some yield components in pea (Pisum sativum ssp. arvense L.) genotypes by using correlation and path analysis. African Journal of Biotechnology. 7(23): 4285-4287.

Toker, C., and Cagirgan, M. I. 2004. The use of phenotypic correlations and factor analysis in determining characters for grain yield selection in chickpea (Cicer arietinum L.). Hereditas. 140: 226-228.

Zhang, Q. 2007. Strategies for developing green super rice. Proceeding of the National Academy of Sciences USA. 104: 16402-16409.

\section{How to cite this article:}

Sujata Das, Lotan Kumar Bose, Bhaskar Chandra Patra, Nitiprasad Namdeorao Jambhulkar, Sudipti Mohapatra and Priyadarsini Sanghamitra. 2019. Genetic Variability and Association of Yield Attributing Traits of Rice Collections of Assam and Arunachal Pradesh. Int.J.Curr.Microbiol.App.Sci. 8(04): 2720-2725. doi: https://doi.org/10.20546/ijcmas.2019.804.316 